\title{
Impact of Biofield Treatment on Chemical and Thermal Properties of Cellulose and Cellulose Acetate
}

Mahendra Kumar Trivedi, Gopal Nayak, Shrikant Patil*, Rama Mohan Tallapragada and Rakesh Mishra

Trivedi Global Inc., 10624 S Eastern Avenue Suite A-969, Henderson, NV 89052, USA

\begin{abstract}
Cellulose being an excellent biopolymer has cemented its place firmly in many industries as a coating material, textile, composites, and biomaterial applications. In the present study, we have investigated the effect of biofield treatment on physicochemical properties of cellulose and cellulose acetate. The cellulose and cellulose acetate were exposed to biofield and further the chemical and thermal properties were investigated. X-ray diffraction study asserted that the biofield treatment did affect the crystalline nature of cellulose. The percentage of crystallite size was found increased significantly in treated cellulose by $159.83 \%$, as compared to control sample. This showed that biofield treatment was changing the crystalline nature of treated cellulose. However treated cellulose acetate showed a reduction in crystallite size (-17.38\%) as compared to control sample. Differential Scanning Calorimetry (DSC) of treated cellulose showed no improvement in melting temperature as compared to control sample. Contrarily cellulose acetate showed significant improvement in melting temperature peak at $351.91^{\circ} \mathrm{C}$ as compared to control $\left(344^{\circ} \mathrm{C}\right)$ polymer. Moreover percentage change in latent heat of fusion $(\Delta \mathrm{H})$ was calculated from the DSC thermogram of both treated and control polymers. A significant increase in percentage $\Delta \mathrm{H}$ of both treated cellulose $(59.09 \%)$ and cellulose acetate $(105.79 \%)$ polymers indicated that biofield treatment enhanced the thermal stability of the treated polymers. CHNSO analysis revealed a significant change in percentage hydrogen and oxygen of treated cellulose $(\% \mathrm{H}-17.77, \% \mathrm{O}-16.89)$ and cellulose acetate $(\% \mathrm{H}-5.67, \% \mathrm{O}-13.41)$. Though minimal change was observed in carbon percentage of both treated cellulose $(0.29 \%)$ and cellulose acetate $(0.39 \%)$ polymers as compared to their respective control samples. Thermo gravimetric analysis and Differential thermo gravimetric (TGA-DTG) analysis of treated cellulose acetate $\left(353^{\circ} \mathrm{C}\right)$ showed increased maximum thermal decomposition temperature as compared to control polymer $\left(351^{\circ} \mathrm{C}\right)$. This showed the higher thermal stability of the treated cellulose acetate polymer; although the maximum thermal decomposition temperature of treated cellulose $\left(248^{\circ} \mathrm{C}\right)$ was decreased as compared to control cellulose $\left(321^{\circ} \mathrm{C}\right)$. These outcomes confirmed that biofield treatment has changed the physicochemical properties of the cellulose polymers.
\end{abstract}

Keywords: Biofield treatment; Cellulose; Cellulose acetate; XRD; DSC; TGA; CHNSO

\section{Introduction}

Polymer based materials; especially naturally occurring biopolymers have been widely used as biomaterials for tissue engineering, artificial skin, wound healing, sutures, tissue constructs, gene delivery, and drug delivery [1]. Cellulose is one of the most abundant naturally occurring biopolymer on earth [2-3]. Several naturally occurring fibers including cotton; and higher plants contain cellulose as their main constituent [4-5]. It consists of long chains of anhydro-D-glucopyranose units (AGU); each cellulose molecule possesses three hydroxyl groups per AGU, with an exception of terminal ends. Cellulose is insoluble in water and in most commonly used organic solvents [3], the poor solubility of cellulose is attributed to strong inter and intra-molecular hydrogen bonding between the individual chains [2].

Cellulose based materials are being employed as components of scaffolds for bone regeneration (Gengiflex ${ }^{\circledR}$ ), artificial blood vessel $\left(\right.$ BASYC $\left.^{\circledR}\right)$, temporary skin substitutes (Biofill $\left.{ }^{\circledR}\right)$, hemodialysis membranes (Cuprophan ${ }^{\circledR}$ and Fresenius Polysulfone ${ }^{\circledR}$ ) and controlled drug release systems [6-10]. In chronic wound dressing, it has provided the moist environment for optimal wound healing due to its ability to absorb water directly into its fibers (AQUACEL ${ }^{\circledR}$ and Cellstick ${ }^{\circledR}$ ) [11]. Recently, cellulose has been proposed to be used as a dialysis membrane for bio artificial pancreas and immuno-isolation of islet transplantation [12].

Cellulose acetate is the ester of cellulose, which is utilized in the production of high-quality fiber mats. Cellulose acetate confers excellent thermal and mechanical properties, which make it an excellent material for diverse applications in engineering, plastics, and biomaterials [13-15]. Ye et al. attempted to prove that the proper surface modification of cellulose acetate can make it fascinating for biomaterial applications [16]. Chemical modification of cellulose was performed to improve processability and to produce cellulose derivatives (cellulosic), which can be tailored to specific industrial applications [17].

Biofield is a cumulative effect, induced by particular human body on external surroundings. Mr. Trivedi is well known to transform the physical and structural properties at the atomic level of the various living and non-living things through his unique biofield. We have previously reported that Mr. Trivedi's biofield, herein referred as Biofield treatment, has significantly enhanced the structural, atomic and thermal properties of transition metals, metal oxides, ceramics and carbon allotropes [18-26].

It was observed that in various ceramic and metal powders, the biofield exposure had substantially changed the lattice parameter, unit cell volume, density, crystallite size and molecular weight. For example, the biofield treatment had increased the particle size by $21.1 \%$

*Corresponding author: Shrikant Patil, Trivedi Global Inc., 10624 S Eastern Avenue Suite A-969, Henderson, NV 89052, USA, Tel:+1 602-531-5400; E-mail: publication@trivedieffect.com

Received: June 03, 2015; Accepted: July 27, 2015; Published: August 07, 2015

Citation: Trivedi MK, Nayak G, Patil S, Tallapragada RM, Mishra R (2015) Impact of Biofield Treatment on Chemical and Thermal Properties of Cellulose and Cellulose Acetate. J Bioengineer \& Biomedical Sci 5: 162. doi:10.4172/2155- 9538.1000162

Copyright: $\odot 2015$ Trivedi MK, et al. This is an open-access article distributed under the terms of the Creative Commons Attribution License, which permits unrestricted use, distribution, and reproduction in any medium, provided the original author and source are credited. 
Citation: Trivedi MK, Nayak G, Patil S, Tallapragada RM, Mishra R (2015) Impact of Biofield Treatment on Chemical and Thermal Properties of Cellulose and Cellulose Acetate. J Bioengineer \& Biomedical Sci 5: 162. doi:10.4172/2155- 9538.1000162

Page 2 of 7

in zirconium oxide which was never been observed in case of ceramics and it was postulated that biofield had caused deformation of the crystals without activating the fracture paths [24]. Additionally, biofield has significantly enhanced the yield and quality of various agriculture products [27-30]. Moreover, Mr. Trivedi's biofield has caused changes in the antibiotic susceptibility patterns as well as produced biochemical reactions that induced changes in the characteristics of pathogenic microbes [31-33]. Furthermore biofield has significantly improved the growth and anatomical characteristics of herb Pogostemon cablin [34].

Having inspired by excellent properties of cellulose and cellulose acetate, we put an attempt to modify the physicochemical parameters of cellulose polymers through biofield treatment, which were characterized for their physicochemical properties by X-ray Diffraction (XRD), Differential Scanning Calorimetry (DSC), Thermo Gravimetric Analysis (TGA) and CHNSO analysis.

\section{Material and Methods}

The powdered sample of cellulose and cellulose acetate were procured from Sigma Aldrich, USA. The procured samples of both the polymers were divided into two parts; one was kept as a control sample, while the other was subjected to Mr. Trivedi's biofield treatment and coded as treated sample.

\section{Characterization of Physicochemical Parameters}

\section{CHNSO analysis}

The control and treated cellulose and cellulose acetate samples were analyzed using CHNSO Analyzer, Model Flash EA 1112 series, Thermo Finnigan, Italy.

\section{$\mathrm{X}$-ray diffraction (XRD) study}

The XRD study of both the cellulose and cellulose acetate powder (control and treated) samples were analyzed by using a Phillips Holland PW 1710 X-ray diffractometer system. A copper anode with nickel filter was used. The wavelength of the radiation was $1.54056 \AA$. The obtained data was used for calculation of crystallite size using the following formula.

\section{Crystallite size $=\mathrm{k} \lambda / \mathrm{b} \cos \theta$}

Where $\lambda$ is the wavelength and $\mathrm{k}$ is the equipment constant (0.94).

\section{Differential scanning calorimetry (DSC)}

The DSC data of cellulose and cellulose acetate (control and treated) samples were analyzed by using Pyris- 6 differential scanning calorimeter (DSC) (Perkin Elmer, USA), at a heating rate of $10^{\circ} \mathrm{C} / \mathrm{min}$ with a nitrogen flow of $5 \mathrm{~mL} / \mathrm{min}$.

\section{Thermo gravimetric analysis (TGA)}

The thermal stability of the cellulose and cellulose acetate samples (control and treated) were analyzed by using a Metller Toledo simultaneous thermo gravimetric analyzer and differential thermal analysis (DTA). The samples were heated from room temperature to $400^{\circ} \mathrm{C}$ with a heating rate of $5^{\circ} \mathrm{C} / \mathrm{min}$ under oxygen atmosphere.

\section{Results}

\section{CHNSO analysis}

The control and treated polymer samples were subjected to CHNSO analysis and data are summarized in (Table 1). The control cellulose sample showed the similar amount of

\begin{tabular}{|c|c|c|}
\hline Parameter & Cellulose & Cellulose Acetate \\
\hline Nitrogen control & 0.00 & 0.00 \\
Nitrogen treated & 0.00 & 0.00 \\
\% change in nitrogen & - & - \\
\hline Carbon control & 41.85 & 47.56 \\
Carbon treated & 41.97 & 47.75 \\
$\%$ change in Carbon & 0.27 & 0.39 \\
\hline Hydrogen control & 5.96 & 5.66 \\
Hydrogen treated & 7.01 & 5.98 \\
\% change in hydrogen & 17.77 & 5.67 \\
\hline Oxygen control & 32.49 & 29.29 \\
Oxygen treated & 37.97 & 33.22 \\
\% change in Oxygen & 16.89 & 13.41 \\
\hline
\end{tabular}

Table 1: CHNSO analysis of cellulose and cellulose acetate.

carbon, hydrogen and nitrogen as reported previously [35]. The treated cellulose polymer showed a very minimal increase in the percentage of carbon $(0.27 \%)$ as compared to control sample. Whereas the significant amount of increased percentage of hydrogen (17.77\%) and oxygen (16.89\%) was observed in treated cellulose as compared to control polymer. However, no nitrogen trace was observed in treated cellulose and cellulose acetate, which showed purity of the samples. The treated cellulose acetate showed an increased $(0.39 \%)$ percentage of carbon as compared to control. The hydrogen and oxygen percentage in treated cellulose acetate increased significantly by $5.67 \%$ and $13.41 \%$ as compared to control polymer. This showed that biofield had changed the elemental composition $(\mathrm{C}, \mathrm{H}$ and $\mathrm{O})$ of the treated cellulose and cellulose acetate polymers.

\section{$\mathrm{X}$-ray diffraction (XRD) analysis}

The XRD studies were conducted on both the control and treated polymers (cellulose and cellulose acetate), and the data are illustrated in [Figure $1(1 \mathrm{a}, 1 \mathrm{~b}, 1 \mathrm{c}$ and $1 \mathrm{~d})$ ]. The XRD diffractogram of control cellulose showed well-defined crystalline peaks (Figure 1a) at $2 \theta$ equals to $16.69^{\circ}$ and $34.37^{\circ}$, which corroborated its crystalline nature. Similarly, the treated cellulose also showed (Figure 1b) two crystalline peaks at $2 \theta$ equals to $16.27^{\circ}$ and $22.53^{\circ}$, which supported the crystalline nature of treated cellulose. According to Wada et al. the peak at $2 \theta$ equals to $16.27^{\circ}$, and $22.53^{\circ}$ reflection could be assigned to (110) and (200) crystallographic plane, respectively [36].

Contrarily, cellulose acetate (control) showed (Figure 1c) more semi-crystalline nature $[37,38]$ as evidenced from two peaks at $2 \theta$ equals to $10.50^{\circ}$ and $13.13^{\circ}$. However, XRD diffractogram of treated cellulose acetate have not showed (Figure 1d) any significant change in peak position.

\section{Differential scanning calorimetry (DSC)}

DSC thermogram of control and treated polymers (cellulose and cellulose acetate) are presented in [Figure 2]. (Figure 2a and 2b) showed a sharp endothermic inflection at $328.51^{\circ} \mathrm{C}$ and $328.32^{\circ} \mathrm{C}$ due to the melting temperature peak of control (Figure 2a) and treated cellulose (Figure $2 \mathrm{~b}$ ), respectively. The higher melting temperature of cellulose material correlated to its high thermal stability. Figure $2 \mathrm{c}$ and $2 \mathrm{~d}$ showed endothermic peaks at $344.14^{\circ} \mathrm{C}$ and $351.91^{\circ} \mathrm{C}$, which was ascribed to melting temperature of control and treated cellulose acetate, respectively. These observed endothermic peak of control (Figure 2c) and treated cellulose acetate (Figure 2d) were much higher than melting temperature reported by Scott [39], Valente et al. [40], and Kee et al. for cellulose acetate polymer [41]. The high melting peak of the treated cellulose acetate was mainly due to excellent thermal stability as compared to control cellulose acetate. 
Citation: Trivedi MK, Nayak G, Patil S, Tallapragada RM, Mishra R (2015) Impact of Biofield Treatment on Chemical and Thermal Properties of Cellulose and Cellulose Acetate. J Bioengineer \& Biomedical Sci 5: 162. doi:10.4172/2155- 9538.1000162

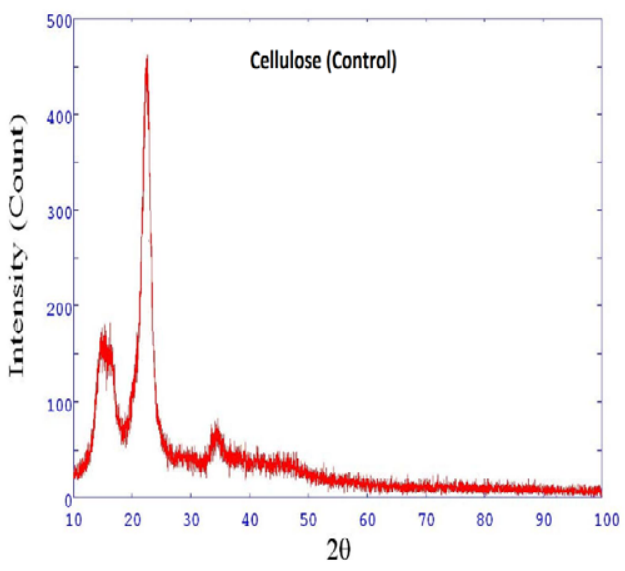

Figure 1a: XRD diffractogram of cellulose (Control).

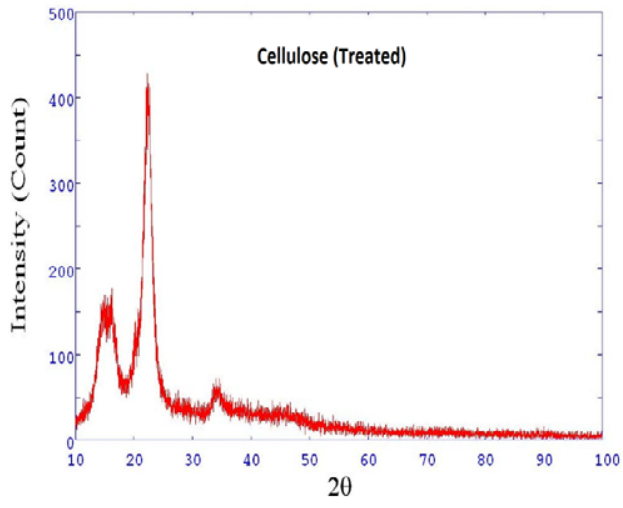

Figure 1b: XRD diffractogram of cellulose (Treated).



Figure 1c: XRD diffractogram of cellulose acetate (Control).

Thermo gravimetric analysis/differential thermal analysis (TGA/DTA):

The TGA/DTA thermogram of control and treated cellulose samples are illustrated in (Figures $3 \mathrm{a}$ and $3 \mathrm{~b}$ ), respectively. TGA thermogram of control cellulose exhibited (Figure 3a) single step thermal degradation pattern at $280-360^{\circ} \mathrm{C}$ where sample lost $69.71 \%$ of its original polymer weight. The maximum decomposition temperature $\left(\mathrm{T}_{\max }\right)$ of control

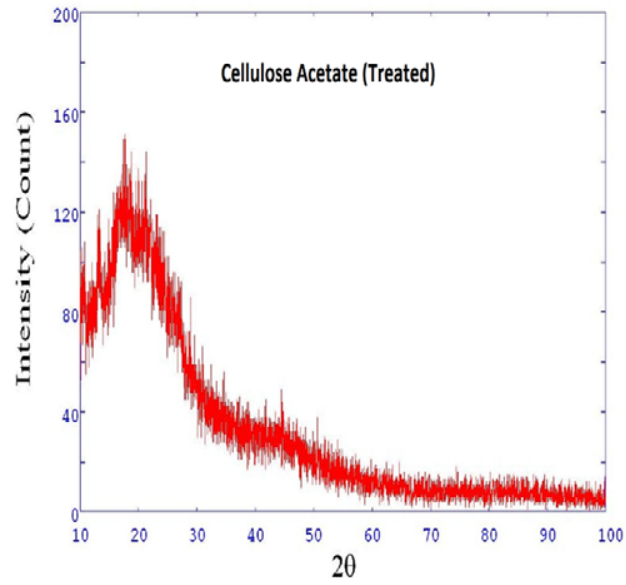

Figure 1d: XRD diffractogram of cellulose acetate (Treated).

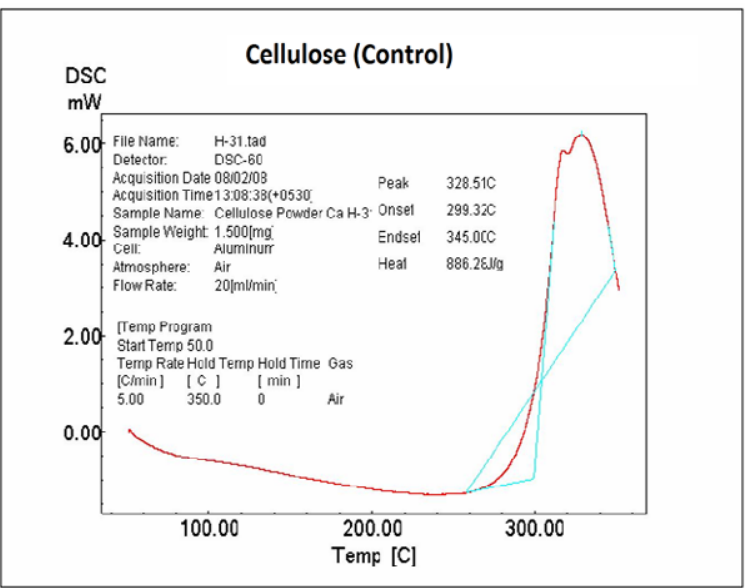

Figure 2a:DSC thermogram of cellulose (Control).

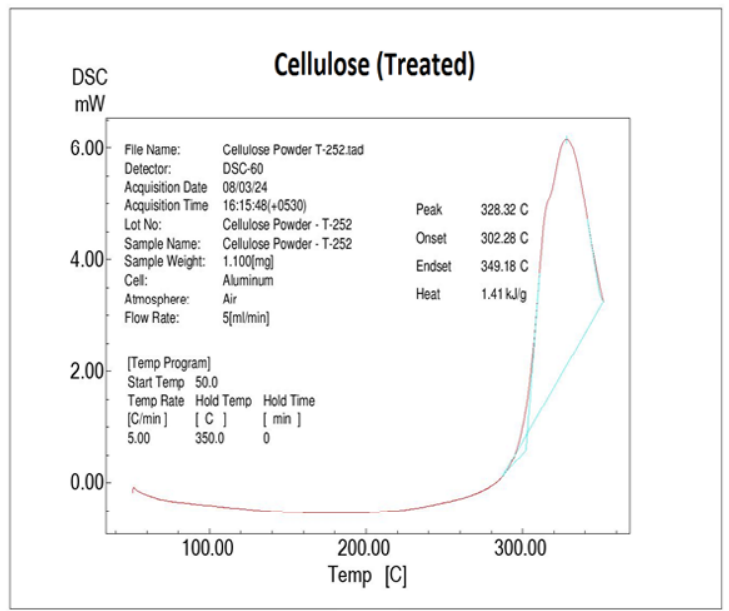

Figure 2b: DSC thermogram of cellulose (Treated)

cellulose was observed at $321.22^{\circ} \mathrm{C}$, which was relatively higher than previously reported value by Rescignano et al. [42]. However, after 
Citation: Trivedi MK, Nayak G, Patil S, Tallapragada RM, Mishra R (2015) Impact of Biofield Treatment on Chemical and Thermal Properties of Cellulose and Cellulose Acetate. J Bioengineer \& Biomedical Sci 5: 162. doi:10.4172/2155- 9538.1000162

Page 4 of 7

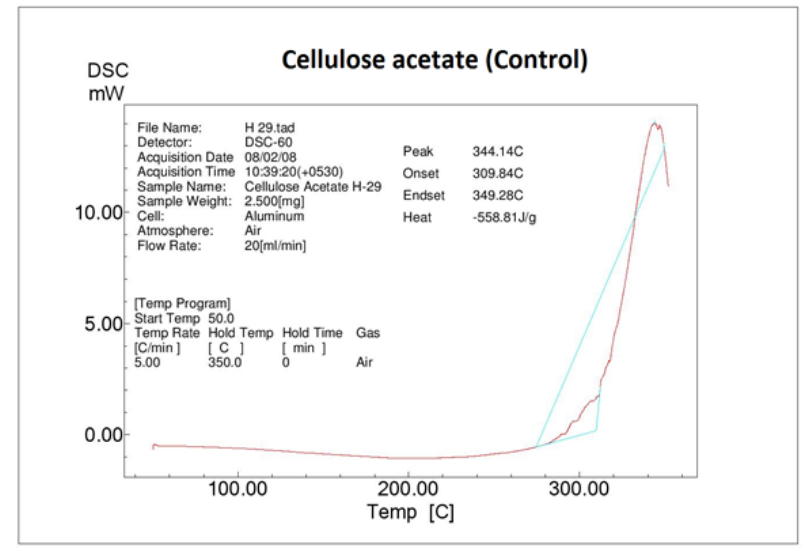

Figure 2c: DSC thermogram of cellulose acetate (Control).

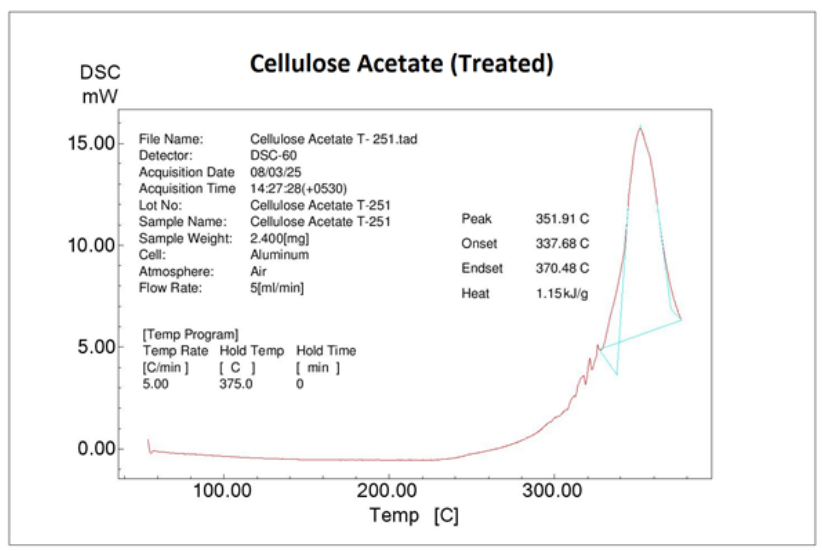

Figure 2d: DSC thermogram of cellulose acetate (Treated). biofield exposure, a decrease was observed in maximum decomposition temperature of treated cellulose $\left(248^{\circ} \mathrm{C}\right)$ as compared to the control sample (Figure 3b).

Figures $3 \mathrm{c}$ and $3 \mathrm{~d}$ showed the TGA thermogram of control and treated cellulose acetate. The control cellulose acetate (Figure $3 \mathrm{c}$ ) sample showed multi-step thermal degradation pattern: polymer started to degrade at $230^{\circ} \mathrm{C}$ and ended at $290^{\circ} \mathrm{C}$, with sample loss of $24.99 \%$; the second thermal decomposition event started at $310^{\circ} \mathrm{C}$ and terminated at $370^{\circ} \mathrm{C}$ with sample loss of $68.08 \%$ from its original polymer weight. Differential thermo gravimetric (DTG) of control cellulose acetate showed maximum decomposition temperature $\left(\mathrm{T}_{\max }\right)$ at $351^{\circ} \mathrm{C}$. Contrarily, the biofield exposed cellulose acetate showed (Figure 3d) single step thermal decomposition pattern $\left(320-390^{\circ} \mathrm{C}\right)$ with $87 \%$ of weight loss.

\section{Discussion}

It was previously suggested that the degree of cellulose crystallinity is one of the most important crystalline structure parameters. The rigidity of cellulose increases with tight inter crystalline packing and their flexibility decreases with increasing ratio of crystalline to amorphous form. Moreover, the free $-\mathrm{OH}$ group along the macromolecule chain of cellulose are involved in a number of inter/intra molecular hydrogen bonding, which may assist in the formation of various long range ordered crystalline planes [43]. The crystalline cellulose is mainly present in four different polymorphic forms (I, II, III, and IV) in nature. On the basis of different investigations, previously it was suggested that cellulose $\mathrm{I}_{\alpha}$ has one chain triclinic structure, and cellulose $\mathrm{I}_{\beta}$ has two chains monoclinic structure.

In the present work, the crystallite size was calculated from the X-ray diffractogram of the control and treated cellulose sample (Table 2). The calculated crystallite size for control cellulose was $10.72 \mathrm{~nm}$, which was increased up to $27.85 \mathrm{~nm}$ in treated cellulose. This increase in crystallite size enhanced the crystallinity indices because the crystalline surface corresponding to amorphous cellulose regions disappeared. The percentage crystallite size in treated cellulose was significantly increased by $159.83 \%$ as compared to control polymer which confirmed that

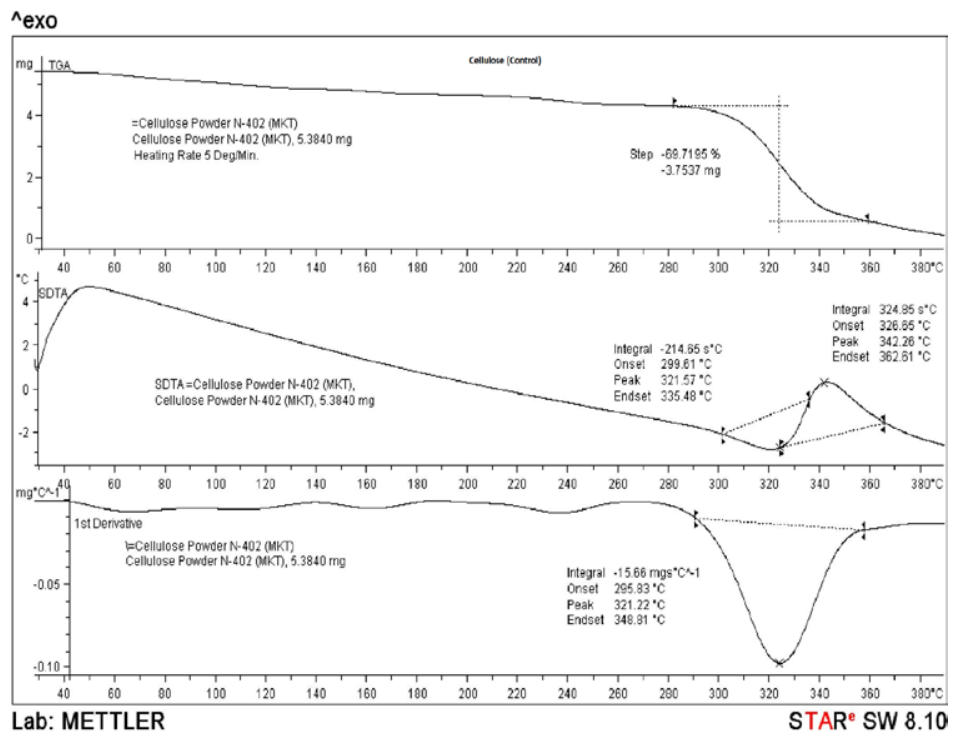

Figure 3a: TGA thermogram of cellulose (Control). 
Citation: Trivedi MK, Nayak G, Patil S, Tallapragada RM, Mishra R (2015) Impact of Biofield Treatment on Chemical and Thermal Properties of Cellulose and Cellulose Acetate. J Bioengineer \& Biomedical Sci 5: 162. doi:10.4172/2155- 9538.1000162

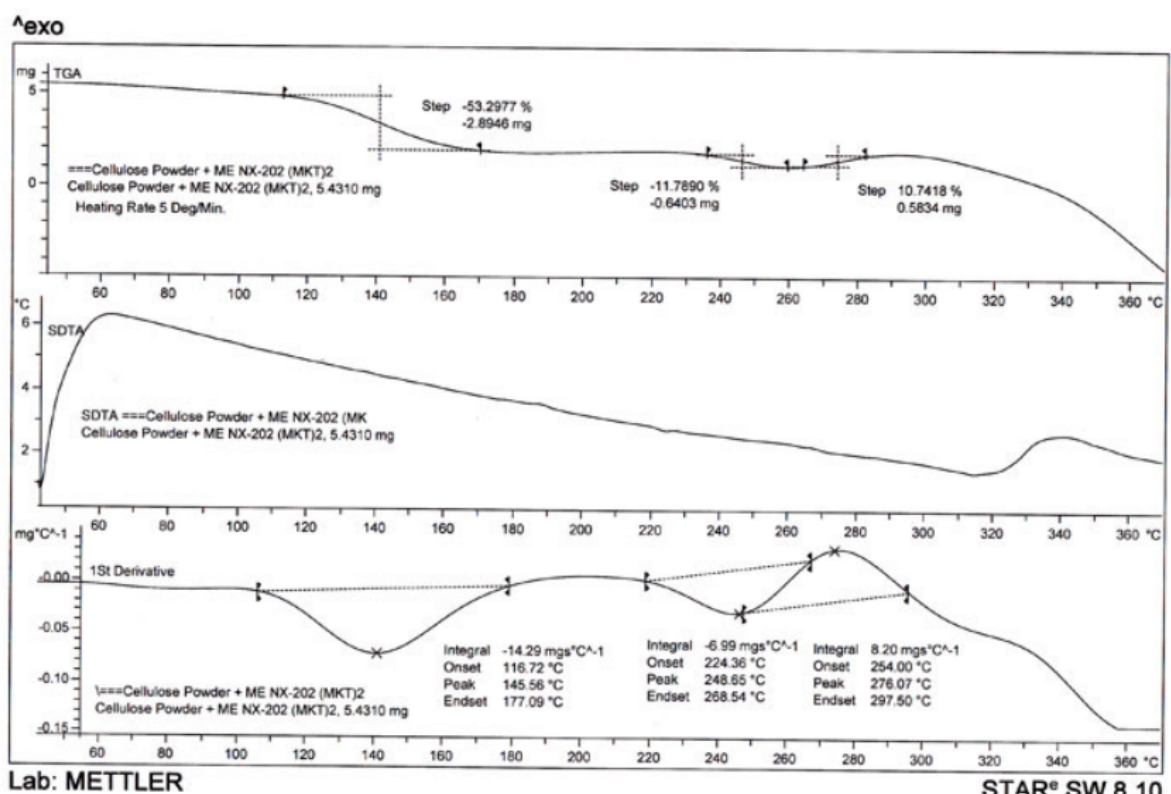

Figure 3b: TGA thermogram of cellulose (Treated).

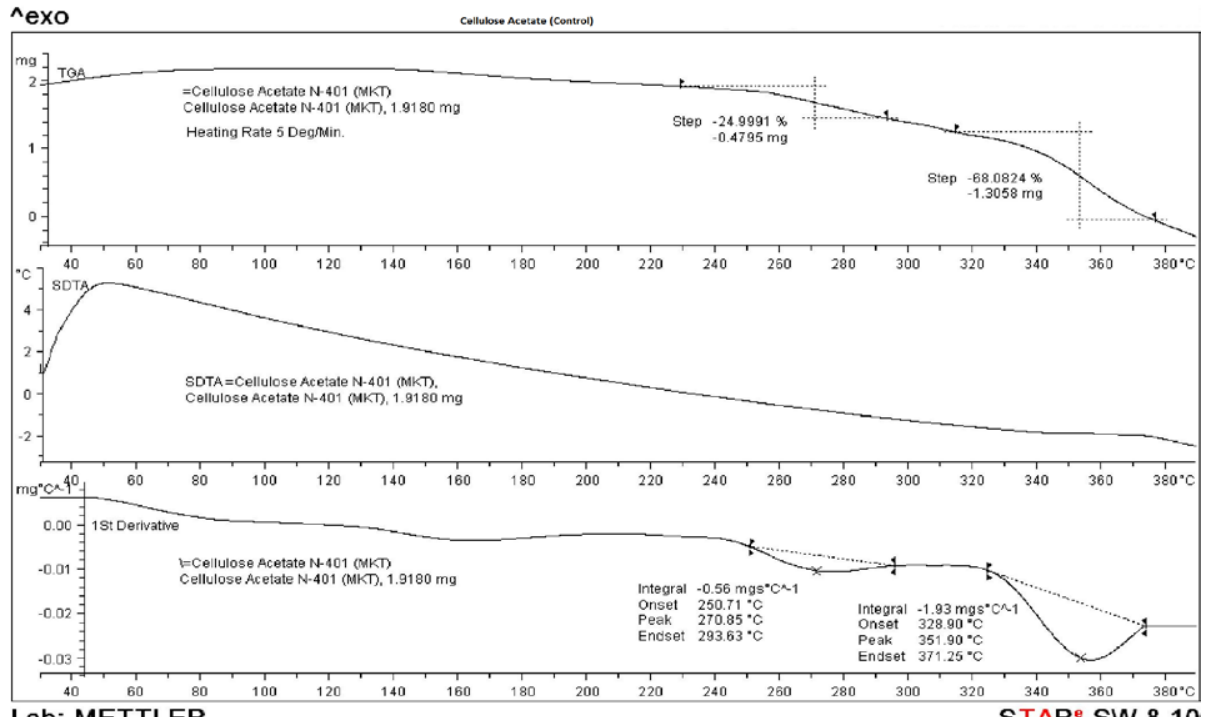

Lab: METTLER

Figure 3c: TGA thermogram of cellulose acetate (Control).

biofield was significantly alleviating the crystalline pattern of cellulose. It was previously demonstrated that cellulose can be converted into a more crystalline stable form by a variety of treatments.

DSC analysis is an important technique to measure the glass transition, melting temperature and change in latent heat of fusion of different materials. The DSC result of treated cellulose showed similar melting temperature $\left(328.51^{\circ} \mathrm{C}\right)$ as showed by the control polymer $\left(328.32^{\circ} \mathrm{C}\right)$. However treated cellulose acetate showed a marked increase $\left(7.77^{\circ} \mathrm{C} \pm 1^{\circ} \mathrm{C}\right)$ in melting peak as compared to control polymer. These findings clearly showed that exposing cellulose acetate to biofield treatment enhanced the thermal stability of the polymer. We presume that biofield has improved the long-range order or regular pattern of atoms, present in the polymer, which lead to improvement in crystallinity. Hence, more thermal energy was required to disturb the crystalline pattern, which increased the thermal stability of treated cellulose acetate. The treated cellulose showed substantially increased percentage latent heat of fusion $(\Delta \mathrm{H}) 59.09 \%$ as compared to control cellulose sample. The increased percentage $\Delta H$ of treated cellulose was may be associated with biofield energy absorption by the polymer. The treated cellulose acetate also showed a significant elevation in percentage $\Delta \mathrm{H}$ of treated cellulose acetate by $105.79 \%$. It was postulated that biofield had caused significant changes in both polymers at the atomic level.

TGA was used to get further insights about the thermal stability 
Citation: Trivedi MK, Nayak G, Patil S, Tallapragada RM, Mishra R (2015) Impact of Biofield Treatment on Chemical and Thermal Properties of Cellulose and Cellulose Acetate. J Bioengineer \& Biomedical Sci 5: 162. doi:10.4172/2155- 9538.1000162

Page 6 of 7

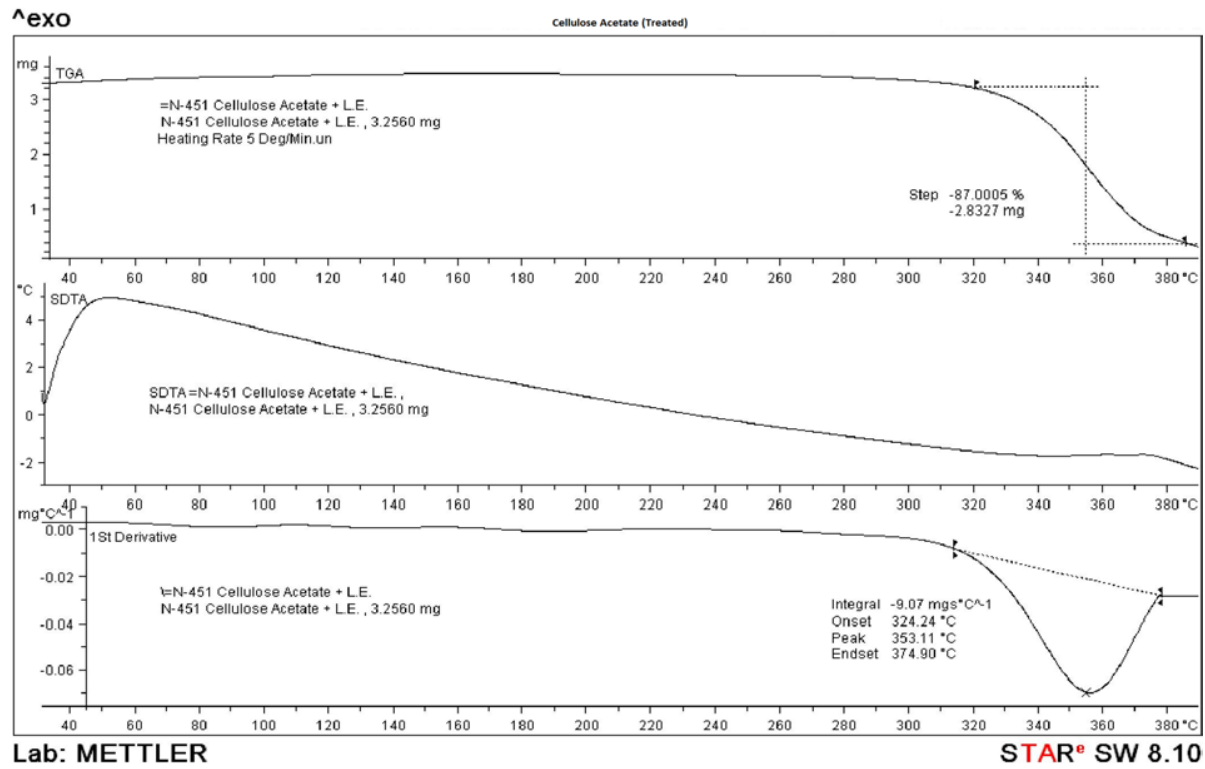

Figure 3d: TGA thermogram of cellulose acetate (Treated).

\begin{tabular}{|c|c|c|c|}
\hline Polymer Powder & \multicolumn{2}{|c|}{ Crystallite size (nano meter) } & Percentage change in \\
crystallite size
\end{tabular}

Table 2: Percentage crystallite size of cellulose and cellulose acetate.

of cellulose and cellulose acetate. The maximum decomposition temperature was observed at $353^{\circ} \mathrm{C}$ based on DTG, which corroborated the improved thermal stability of the treated cellulose acetate as compared to control polymer $\left(351^{\circ} \mathrm{C}\right)$; this was well supported by our DSC results.

Cellulose based polymers have been used commonly for wound dressing and tissue regeneration applications. The wound dressing and skin repair materials should have excellent ability to absorb exudates, prevent bacterial infection, inhibit bleeding and maintain proper water, electrolyte balance [44]. Nevertheless, due to low strength and elasticity some commercial wound dressings did not satisfy ideal healing requirements as they tend to stick to wound surface or crushed under high stress [45]. The cellulose acetate polymer is a hydrophilic polymer with good liquid transport and water absorption abilities. However, poor mechanical and resistance properties limit its applications as a wound dressing material. Hence, in present work cellulose acetate and cellulose were treated with biofield to improve its physicochemical properties. Our XRD and DSC result demonstrated the significant increase in crystalline and thermal properties of these polymers (cellulose and cellulose acetate) after biofield exposure. It was expected that increased crystalline nature and high temperature stability may confer excellent mechanical properties that will be crucial for its wound healing applications.

\section{Conclusion}

The present work reports the effect of Mr. Trivedi's biofield on chemical and thermal properties of cellulose based polymers (cellulose and cellulose acetate). The XRD studies revealed well-defined crystalline behavior for both control cellulose and biofield treated sample.
Biofield treated sample showed greater crystallite size as compared to control cellulose, which was quite unexpected, and we hypothesize that biofield was inducing more long range order between the atoms alleviating its crystalline nature. Though a decrease in crystallite size was observed in treated cellulose acetate as compared to control sample.

The DSC thermogram of control cellulose showed no change in melting behavior, on the other hand, treated cellulose acetate showed enhanced melting temperature peak, which revealed the high thermal stability of the respective polymer. CHNSO results corroborated substantial increase in percentage hydrogen and oxygen of treated polymers (cellulose and cellulose acetate) as compared to control sample. TGA analysis confirmed the higher thermal stability of treated cellulose acetate as compared to control; however thermal stability was decreased in treated cellulose as compared to control. Energy from the Biofield treatment that was absorbed by the treated samples might have played an important role that caused a substantial increase in the latent heat of fusion of both the treated samples. Based on the results achieved, we conclude that the biofield treated polymers could play an important role in the applications of wound dressing materials.

\section{Acknowledgment}

The authors thank to staff of various laboratories for their constant support in instrumental handling. We also extend our gratitude to Dr. Cheng Dong of NLSC Institute of Physics, and Chinese academy of Sciences for allowing us to use Powder X software for analyzing XRD data.

\section{References}

1. Dhandayuthapani B, Yoshida Y, Maekawa T, Kumar DS (2011) Polymeric Scaffolds in Tissue Engineering Application: A Review. International Journa of Polymer Science 2011.

2. Hinterstoisser B, Salmen L (2000) Application of dynamic 2D FTIR to cellulose. Vibrational Spectroscopy 22: 111-118.

3. Bochek AM (2003) Effect of hydrogen bonding on cellulose solubility in aqueous and non-aqueous solvents. Russian Journal of Applied Chemistry 76: 1711-1719.

4. Myasoedova VV (2000) Physical chemistry of non-aqueous solutions of cellulose and its derivatives. John Wiley and Sons, Chichester. 
Citation: Trivedi MK, Nayak G, Patil S, Tallapragada RM, Mishra R (2015) Impact of Biofield Treatment on Chemical and Thermal Properties of Cellulose and Cellulose Acetate. J Bioengineer \& Biomedical Sci 5: 162. doi:10.4172/2155- 9538.1000162

5. Gross RA, Scholz C (2001) Biopolymers from polysaccharides and agro proteins. American Chemical Society, Washington, p. 786.

6. Fontana JD, de Souza AM, Fontana CK, Torriani IL, Moreschi JC, et al (1990) Acetobacter cellulose pellicle as a temporary skin substitute. Applied Biochemistry and Biotechnology 24-25: 253-264.

7. Harsh DC, Gehrke SH (1991) Controlling the swelling characteristics of temperature-sensitive cellulose ether hydrogels. Journal of Controlled Release 17: $175-186$

8. Marques AP, Reis RL, Hunt JA (2002) The biocompatibility of novel starchbased polymers and composites: In-vitro studies. Biomaterials, 23: 1471-1478.

9. Hoenich NA, Stamp S (2000) Clinical investigation of the role of membrane structure on blood contact and solute transport characteristics of a cellulose membrane. Biomaterials 21: 317-324.

10. Klemm D, Schumann D, Udhardt U, Marsch S (2001) Bacterial synthesized cellulose-artificial blood vessels for microsurgery. Progress in Polymer Science 26: 1561-1603.

11. Moseley R, Walker M, Waddington RJ, Chen WY (2003) Comparison of the antioxidant properties of wound dressing materials carboxy methylcellulose, hyaluronan benzyl ester and hyaluronan, towards polymorphonuclear leukocyte-derived reactive oxygen species. Biomaterials 24: 1549-1557.

12. Vogrin N, Stropnik C, Musil V, Brumen M (2002) The wet phase separation: The effect of cast solution thickness on the appearance of macrovoids in the membrane forming ternary cellulose acetate/acetone/water system. Journal of Membrane Science 207: 139-141.

13. Rahimpour A, Madaeni SS (2007) Polyethersulfone (PES)/cellulose acetate phthalate (CAP) blend ultrafiltration membranes: Preparation, morphology, performance and antifouling properties. Journal of Membrane Science 305: 299-312.

14. Malaisamy R, Mahendran R, Mohan D, Rajendran M, Mohan V (2002) Cellulose acetate and sulfonatedpolysulfone blend ultrafiltration membrane. I. Preparation and characterization. Journal of Applied Polymer Science 86: 1749-1761.

15. Risbud MV, Bhonde RR (2001) Suitability of cellulose molecular dialysis membrane for bio artificial pancreas: in vitro biocompatibility studies. J Biomed Mater Res 54: 436-444.

16. Ye SH, Watanabe J, Iwasaki Y, Ishihara K (2005) In situ modification on cellulose acetate hollow fibre membrane modified with phospholipid polymer for biomedical application. Journal of Membrane Science 249: 133-141.

17. Akira I (2001) Chemical modification of cellulose. In Wood and Cellulosic Chemistry (Eds D.N.S. Hon and N Shiraishi), New York: Marcel Dekker.

18. Trivedi MK, Tallapragada RR (2008) A transcendental to changing metal powder characteristics. Metal Powder Report 63: 22-28, 31.

19. DabhadeVV ,Tallapragada RR, Trivedi MK (2009) Effect of external energy on atomic crystalline and powder characteristics of antimony and bismuth powders. Bulletin of Materials Science 32: 471-479.

20. Trivedi MK, Tallapragada RR (2009) Effect of super consciousness external energy on atomic crystalline and powder characteristics of carbon allotrope powders. Materials Research Innovations 13: 473-480.

21. Trivedi MK, Patil S, Tallapragada RM (2012)Thought Intervention through Bio field Changing Metal Powder Characteristics Experiments on Powder Characterization at a PM Plant. Springer Berlin Heidelberg 173: 247-252.

22. Trivedi MK, Patil S, Tallapragada RM (2013) Effect of Bio field Treatment on the Physical and Thermal Characteristics of Vanadium Pentoxide Powders. Journal of Material Sciences and Engineering.

23. Trivedi MK, Patil S, Tallapragada RM (2013) Effect of bio field treatment on the physical and thermal characteristics of Silicon Tin and Lead powders. J Material Sci Eng 2: 125.

24. Trivedi MK, Patil S, Tallapragada RM (2014) Atomic Crystalline and Powder Characteristics of Treated Zirconia and Silica Powder. Journal of Materia Sciences and Engineering 3: 144

25. Trivedi MK, Patil S, Tallapragada RMR (2015) Effect of Bio field Treatment on the Physical and Thermal Characteristics of Aluminium Powders. Ind Eng Manage 4: 151.

26. Trivedi MK, Nayak G, Patil S, Tallapragada RM, Latiyal O (2015) Studies of the
Atomic and Crystalline Characteristics of Ceramic Oxide Nano Powders after Bio field Treatment. Ind Eng Manage 4: 161

27. Shinde V, Sances F, Patil S, Spence A (2012) Impact of Bio field Treatment on Growth and Yield of Lettuce and Tomato. Australian Journal of Basic and Applied Sciences 6: 100

28. Sances F, Flora E, Patil S, Spence A, Shinde V (2013) Impact of Bio field Treatment on Ginseng and Organic Blueberry Yield. Agrivita Journal of Agricultural Science 35: 22-29.

29. Lenssen AW (2013) Bio field and Fungicide Seed Treatment Influences on Soybean Productivity Seed Quality and Weed Community. Agricultural Journal 8: 138-143.

30. Altekar N, Nayak G (2015) Effect of Bio field Treatment on Plant Growth and Adaptation. Journal of Environment and Health sciences 1: 1-9.

31. Trivedi M, S Patil (2008)Impact of an external energy on Staphylococcus epidermis [ATCC -13518] in relation to antibiotic susceptibility and biochemica reactions - An experimental study. Journal of Accord Integrative Medicine 4: 230-235.

32. Trivedi M, Patil S (2008) Impact of an external energy on Yersinia enterocolitica [ATCC -23715 ] in relation to antibiotic susceptibility and biochemical reactions - An experimental study. The Internet Journal of Alternative Medicine 6.

33. Trivedi M, Bhardwaj Y, Patil S, Shettigar H, Bulbule A (2009) Impact of an external energy on Enterococcus faecalis [ATCC - 51299] in relation to antibiotic susceptibility and biochemical reactions - An experimental study. Journal of Accord Integrative Medicine 5: 119-130.

34. Patil SA, Nayak GB, Barve SS, Tembe RP, Khan RR (2012) Impact of Bio field Treatment on Growth and Anatomical Characteristics of Pogostemoncablin (Benth). Biotechnology 11: 154-16.

35. Bouhdadi R, Benhadi S, Molina S, George B, Moussaouiti ME, et al. (2011) Chemical modification of cellulose by acylation application to adsorption of methylene blue. MaderasCiencia y tecnología 13: 105-116.

36. Wada M, Okano T (2001) Localization of I $\alpha$ and I $\beta$ phases in algal cellulose revealed by acid treatments. Cellulose 8: 183-188.

37. Kim UJ, Eom SH, Wada M (2010) Thermal decomposition of native cellulose: Influence on crystallite size. Polymer Degradation and Stability 95: 778-781.

38. Mishra A, Bajpai M (2005) Flocculation behaviour of model textile wastewater treated with a food grade polysaccharide. Journal of Hazardous Materials 118: 213-217.

39. Scott K (1995) Handbook of Industrial Membranes. Oxford Elsevier Science.

40. Valente AJM, Polishchuk AY, Burrows HD, Lobo VMM (2005) Permeation of water as a tool for characterizing the effect of solvent film thickness and water solubility in cellulose acetate. European Polymer Journal 41: 275-281.

41. Kee CM, Idris A(2010) Permeability performance of different molecular weight cellulose acetate hemodialysis membrane. Separation and Purification Technology 75: 102-113.

42. Rescignano NE, Armentano F, Hernandez IR, Mijangos C, Pasquino R, et al. (2015) Use of alginate chitosan and cellulose nanocrystals as emulsion stabilizers in the synthesis of biodegradable polymeric nanoparticles. Journal of Colloid and Interface Science 445: 31-39.

43. Kamal H, Abd-Elrahim FM, Lotfy S (2014) Characterization and some properties of cellulose acetate-co-polyethylene oxide blends prepared by the use of gamma irradiation. Journal of Radiation Research and Applied Sciences 7: 146-153.

44. Zahedi P, Rezaeian I, Ranaei-Siadat SO, Jafari SH, Supaphol P (2010) A review on wound dressings with an emphasis on electro-spunnano fibrous polymeric bandages. Polymer for Advance Technologies 21: 77-95.

45. Yoshii F, Zhanshan Y, Isobe K, Shiozaki K, Makunchi K (1999) Electron beam cross-linked PEO and PEO/PVA hydrogels for wound dressing. Radiation Physics and Chemistry 55: 133-138. 